\title{
KAJIAN DAYA TAMPUNG BEBAN PENCEMARAN SENYAWA AOX DI SUNGAI CIUJUNG DENGAN MODEL WASP (WATER QUALITY ANALYSIS SIMULATION PROGRAM)
}

\author{
STUDY OF AOX COMPOUND POLLUTION LOAD CAPACITY \\ IN CIUJUNG RIVER WITH WASP MODEL (WATER QUALITY \\ ANALYSIS SIMULATION PROGRAM)
}

\author{
Heny Hindriani ${ }^{1}$ \\ ${ }^{1}$ Program Studi Kimia, Sekolah Tinggi Analis Kimia Cilegon, Email: henyhindriani10@gmail.com
}

\begin{abstract}
ABSTRAK
Senyawa organik terklorinasi (AOX, Adsorbable Organic Halides) merupakan kumpulan senyawa organik yang mengandung halida dan memiliki karakteristik beracun, hidrofobik, bioakumulatif, karsinogen, dan persisten. Penelitian ini bertujuan untuk menetapkan daya tampung beban pencemaran Senyawa AOX dengan pemodelan WASP (water Quality analysis simulation program). Hasil penelitian menunjukkan bahwa telah terjadi peningkatan kualitas air sungai Ciujung untuk kelas II sebesar 81,82\% dari $13.75 \mathrm{~km}$ menjadi $25 \mathrm{~km}$ dan peningkatan daya tampung beban pencemaran rata-rata menjadi 57,42 kg/hari ketika debit dinaikan dari $1.9 \mathrm{~m}^{3} /$ detik menjadi $29.9 \mathrm{~m}^{3} /$ detik dan beban pencemaran dari point source direduksi sebesar $90 \%$,
\end{abstract}

Kata Kunci : Sungai Ciujung, AOX, Daya tampung beban pencemaran, WASP

\begin{abstract}
Chlorinated organic compounds (AOX, Adsorbable Organic Halides) are a collection of organic compounds that contain halides and have toxic, hydrophobic, bioaccumulative, carcinogenic, and persistent characteristics. This study aims to determine the carrying capacity of the AOX compound pollution load using WASP (water Quality analysis simulation program) modeling. The results showed that there had been an increase in the water quality of the Ciujung River for class II by $81.82 \%$ from $13.75 \mathrm{~km}$ to $25 \mathrm{~km}$ and an increase in the average pollution load capacity of $57.42 \mathrm{~kg} /$ day when the discharge was increased from $1.9 \mathrm{~m} 3 / \mathrm{second}$ to $29.9 \mathrm{m3} / \mathrm{second}$ and the pollution load from the point source is reduced by $90 \%$,
\end{abstract}

Keyword : Ciujung River, AOX, Pollution load capacity, WASP

\section{Pendahuluan}

Sungai Ciujung, seperti halnya sungai di Indonesia pada umumnya juga mengalami masalah pencemaran, penurunan kualitas air sungai, penurunan debit air terutama pada musim kemarau dan pendangkalan sungai. Sungai ini merupakan sungai utama yang berada di Provinsi Banten dengan panjang 147.2 km dan luas DAS 217,197.89 ha. Bagian hulu Sungai Ciujung berada di Kabupaten Lebak, bagian hilirnya berada di Kabupaten Serang dan sebagian masuk ke Provinsi Jawa Barat, sehingga sungai ini menjadi kewenangan pusat. Sungai Ciujung memegang peranan penting sebagai pensuplai air berbagai kegiatan industri, perikanan, pertanian maupun domestik (KLH 2004, DLH 2017). 
Pencemaran yang terjadi di Sungai Ciunjung sudah sangat meng-khawatirkan akibat masih terdapatnya lahan kritis di daerah hulu sungai yang berada di Kabupaten Lebak seluas $\pm 11,114$ ha dan adanya kegiatan industri di daerah hilir yaitu di Kabupaten Serang, sehingga Sungai Ciujung mengalami degradasi lingkungan yang cukup signifikan baik dilihat dari kuantitas maupun kualitasnya. Dimana secara kuantitas debit Sungai Ciujung mengalami penurunan kondisi normal sebesar $\pm 50 \mathrm{~m}^{3} /$ detik menjadi hanya $\pm(2-3) \mathrm{m}^{3} /$ detik bahkan 0 $\mathrm{m}^{3}$ /detik pada musim kemarau (DL $\overline{\mathrm{H}}, 2017$ ).

Industri yang membuang air limbahnya langsung ke Sungai Ciujung adalah Industri kertas dan industri kimia, sementara industri yang berada di dalam Kawasan Industri membuang air limbahnya ke Sungai Cikambuy yang merupakan anak Sugai Ciujung. Salah satu Indikator telah terjadinya penurunan kualitas air Sungai Ciujung adalah meningkatnya nilai BOD, COD, ammonia, logam berat dan parameter kimia fisika lainnya seperti yang tertuang dalam peraturan pemerintah Nomor 82 Tahun 2001 tentang pengelolaan kualitas air dan pengendalian pencemaran air. Namun parameter senyawa organik terklorinasi (AOX : Adsorbable Organic Halides) belum mendapat perhatian khusus dari pemerintah Indonesia sehingga baku mutunya belum ditetapkan baik dalam effluent limbah cair maupun dalam badan air. Padahal menurut Yasmidi (2008), konsentrasi senyawa AOX di beberapa sungai di Indonesia yang melintasi industri pulp dan kertas sudah cukup tinggi, seperti yang terjadi pada Sungai Siak dan Sungai Kampar yang berada di Provinsi Riau. Senyawa AOX di Sungai tersebut terbioakumulasi dalam ikan sehingga ikan dalam daerah $4 \mathrm{~km}$ ke hulu dan $16 \mathrm{~km} \mathrm{ke}$ hilir effluent diprediksi tidak layak untuk dikonsumsi.

Beberapa negara lain seperti Amerika, Brazil, Finlandia, Kanada, Prancis, Selandia baru dan Swedia telah menerapkan baku mutu senyawa AOX, sedangkan di Indonesia penerapan baku mutu AOX baru dilakukan secara sukarela di beberapa industri pulp dan kertas, misalnya di PT Indah Kiat Pulp and Paper Di Perawang Riau dimana berkisar pada $0.2-0.4 \mathrm{~kg} / \mathrm{ADT}$ (untuk non ECF) dan 0.1 - 0.25 (untuk ECF). Sedangkan di PT Tanjung Enim Lestari berada pada kisaran 3.7 - $6.8 \mathrm{~kg} / \mathrm{ADT}$ (untuk non ECF) dan 0.9 - $1.7 \mathrm{~kg} / \mathrm{ADT}$ (untuk ECF) (Rosita, 2003).

Untuk mengatasi masalah pencemaran tersebut, perlu dilakukan pengendalian pencemaran air. Menurut Peraturan Pemerintah RI Nomor 82 tahun 2001 tentang Pengelolaan Kualitas Air dan Pengendalian Pencemaran Air, penetapan daya tampung beban pencemaran (DTBP) air merupakan salah satu upaya pengendalian pencemaran yang perlu dilakukan oleh pemerintah dan pemerintah propinsi, pemerintah kabupaten/kota sesuai dengan kewenangan masing-masing. Penetapan DTBP juga perlu dilakukan apabila kontrol teknologi tidak memadai untuk mencapai standar kualitas air yang dipersyaratkan ( US EPA 2008).

Pemodelan kualitas air yang digunakan untuk penetapan DTBP dalam penelitian ini adalah water quality analysis simulation program (WASP). WASP adalah model dinamis yang dapat digunakan untuk menganalisis berbagai masalah kualitas air pada beragam badan air seperti pada kolam, sungai, danau, waduk, muara, dan perairan pesisir berdasarkan pada prinsip utama konservasi massa. Prinsip ini mensyaratkan bahwa massa dari masing-masing bagian kualitas air yang diteliti harus diperhitungkan dalam satu bagian (Ambrose 2005). Model WASP mengkaji setiap bagian kualitas air berdasarkan input spasial dan temporal dari titik awal hingga ke titik akhir perpindahan, berdasarkan prinsip konsenrvasi massa dalam ruang dan waktu (Ambrose 2009).

Penelitian ini bertujuan untuk menetapkan daya tampung beban pencemaran Sungai Ciujung berdasarkan parameter senyawa AOX pada debit andalan minimum dan maksimum dengan berbagai reduksi beban pencemaran. 
Jurnal SEOI - Fakultas Teknik Universitas Sahid Jakarta

Vol 1 edisi 1 tahun 2019

\section{Metodologi Penelitian}

\subsection{Penentuan Segmentasi}

Sungai Ciujung sepanjang $31.75 \mathrm{~km}$ dibagi menjadi 16 segmen berdasarkan sumber pencemar dan karakteristik hidrolika sungai.

\subsection{Penetapan Lokasi Sampling, Pengambilan Dan Analisis Sampel}

Pengambilan sampel dilakukan pada 16 titik yang dapat mewakili kualitas air sungai dari hulu sampai hilir (Gambar 1). Pengambilan sampel air mengacu pada standar SNI 06-24211991, sementara parameter AOX dianalisis dengan metoda mikrokolometri yang mengacu pada SNI 7228.2:2011.

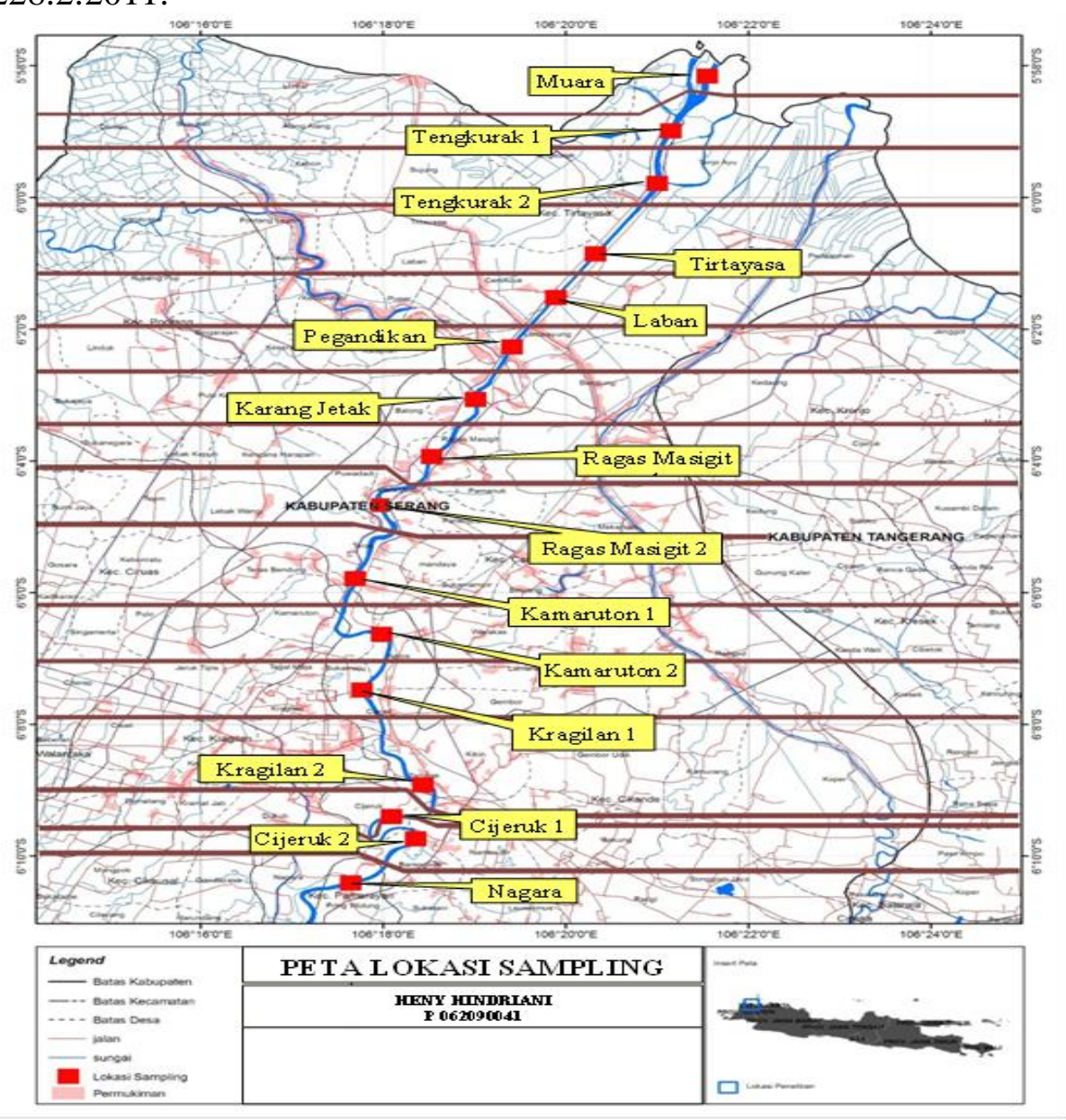

Gambar 1. Lokasi pengambilan sampel

\subsection{Pengumpulan Data}

Data dalam penelitian ini diperoleh dari beberapa lembaga/ instansi terkait, hasil survey lapangan dan analisis laboratorium.

Tabel 1 Jenis dan sumber data

\begin{tabular}{ll}
\hline \multicolumn{1}{c}{ Data } & \multicolumn{1}{c}{ Sumber } \\
\hline - Peta topografi & - Bakosurtanal \\
- Debit sungai harian & - Dinas PU, BBWS \\
- Data hidrolika (kecepatan air, kedalaman, waktu yang & - Pengukuran langsung \\
ditempuh masa air) & \\
- Data klimatologi (evaporasi), & - BMKG, BPS \\
- Penampang melintang sungai & - Dinas PU \\
- Penampang memanjang sungai, & - Dinas PU
\end{tabular}




\begin{tabular}{ll}
\hline \multicolumn{1}{c}{ Data } & \multicolumn{1}{c}{ Sumber } \\
\hline - Lokasi sumber pencemar & - Observasi lapangan \\
- Debit limbah industri & - Pengukuran langsung \\
- Kualitas limbah industri & - BLH \\
& - Hasil analisis (in situ dan laboratorium) \\
& - BPS \\
- Kualitas air sungai. & - Dinas kependudukan dan catatan sipil \\
\hline
\end{tabular}

\subsection{Penetapan Potensi Beban Pencemar Senyawa AOX}

Beban pencemaran senyawa AOX berasal dari point source (limbah industri yang dihitung dengan mengalikan konsentrasi senyawa AOX dalam limbah cair dari masing-masing outlet industri dengan masing-masing debit dan kapasitas produksi hariannya.

\subsection{Pemodelan dengan Program WASP 7.3}

Pemodelan kualitas air menggunakan program WASP7.3 dengan metoda finite segment.

\subsection{Kalibrasi Model}

Kalibrasi model ditentukan dengan metoda least square menggunakan analisis regresi.

\subsection{Debit Andalan Sungai Ciujung}

Data debit harian selama 15 tahun terakhir diambil dari data stasiun pos duga automatik (PDA) yang berada di Desa Undar Andir. Debit andalan ditentukan dengan menghitung debit rata rata bulanan menggunakan data debit harian dari bulan Januari sampai bulan Desember, mengurutkan data debit harian dari besar ke kecil dengan mengabaikan tahun, melakukan perhitungan probabilitas $80 \%$ dari data yang telah diurutkan dengan persamaan :

$$
80 / 100=n /(m+1)
$$

Dimana $\mathrm{n}$ adalah urutan ranking dan $\mathrm{m}$ adalah jumlah sampel

\subsection{Aplikasi Model Kualitas Air}

Model yang sudah terkalibrasi selanjutnya digunakan untuk simulasi pada berbagai debit andalan dengan mereduksi beban pencemaran. Konsentrasi Senyawa AOX sepanjang sungai dari hasil model, digunakan untuk menghitung beban pencemaran. Beban pencemaran terukur hasil model kemudian dibandingkan dengan beban pencemaran BOD dan Senyawa AOX yang diijinkan, sehingga daya tampung beban pencemaran BOD dan senyawa AOX sepanjang Sungai Ciujung dapat diketahui.

Tahapan penelitian secara keseluruhan disajikan dalam Gambar 2. 
Jurnal SEOI - Fakultas Teknik Universitas Sahid Jakarta

Vol 1 edisi 1 tahun 2019

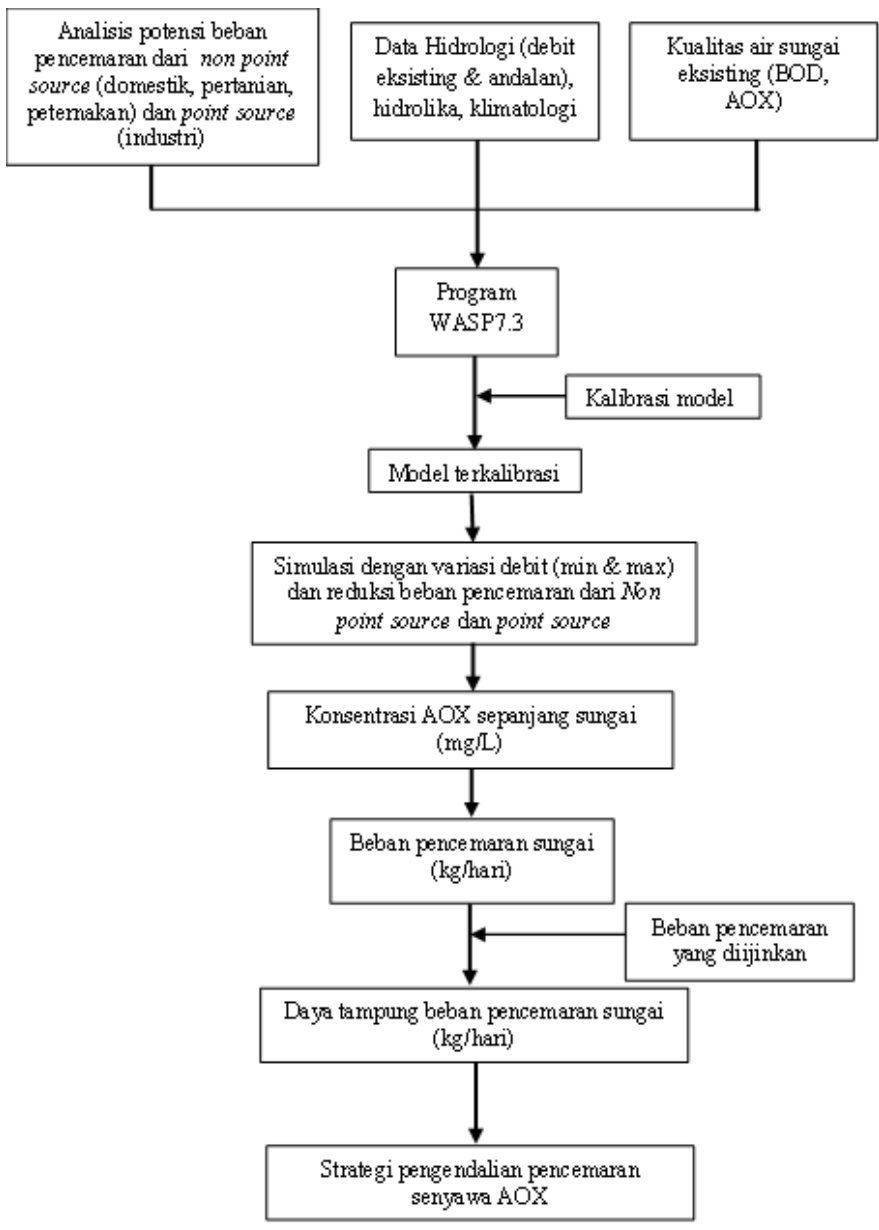

Gambar 2. Tahapan Penelitian

\section{Hasil dan Pembahasan}

\subsection{Debit Andalan}

Debit andalan Sungai Ciujung ditetapkan dari data debit selama 15 tahun dengan probabilitas $80 \%$. Debit andalan minimum terjadi pada pada Bulan Agustus ( $1.9 \mathrm{~m}^{3} / \mathrm{detik}$ ) dan debit maksimum pada Bulan Februari (29.9 $\mathrm{m}^{3} /$ detik). Debit ini selanjutnya digunakan untuk simulasi pemodelan kualitas air Sungai Ciujung

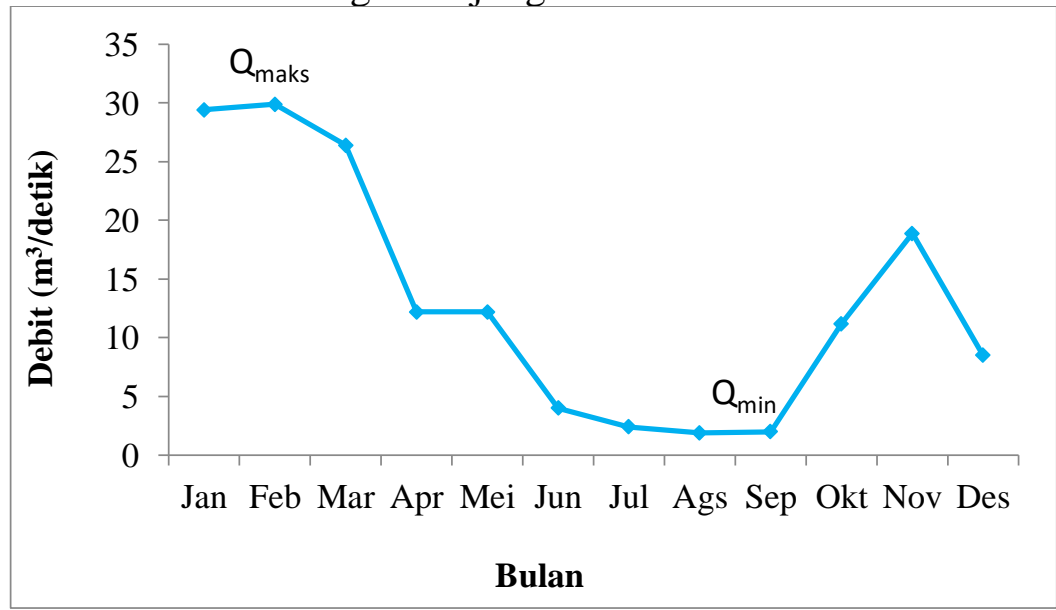

Gambar 3 Debit andalan Sungai Ciujung tahun 1997-2011 


\subsection{Kalibrasi Model}

Kalibrasi model adalah proses mencari nilai-nilai parameter kinetik untuk mencapai kecocokan yang terbaik (goodness of fit) antara hasil pemodelan dan hasil pengukuran kualitas air di badan sungai atau mempunyai kecenderungan yang sama dengan kondisi di lapangan (Yusuf 2004).
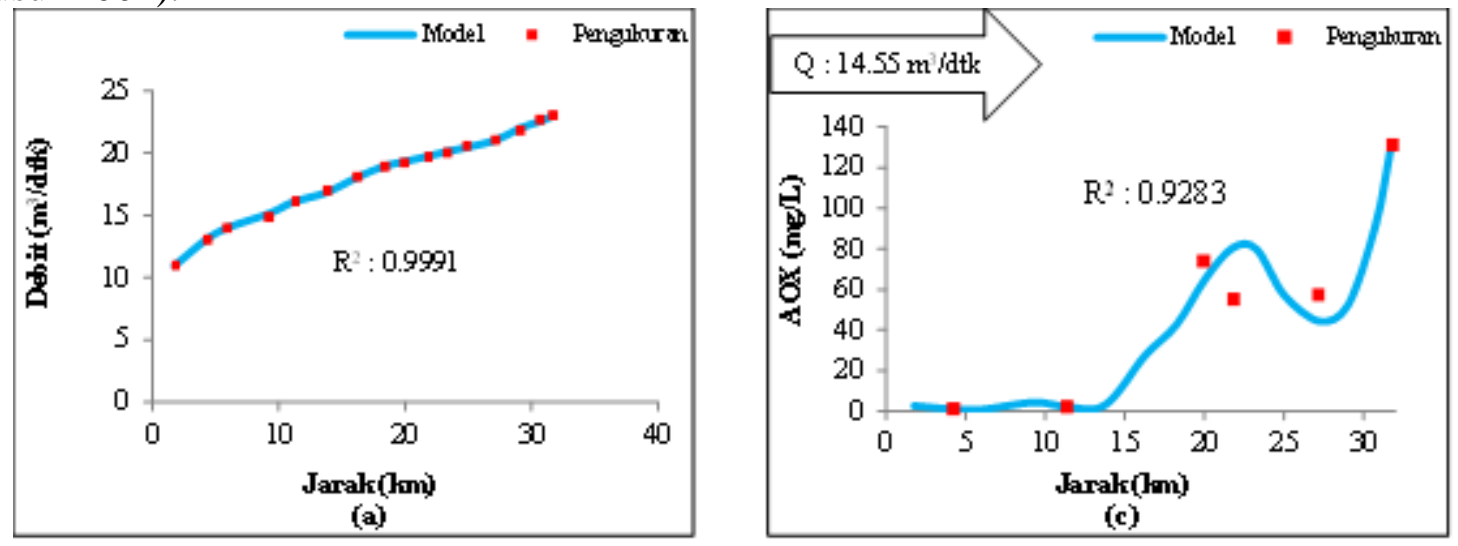

Gambar 4. Grafik Kalibrasi (a) Debit, dan (b) senyawa AOX

Gambar 4, memperlihatkan bahwa terdapat kesesuaian trend yang cukup baik antara data hasil pengukuran di lapangan dengan hasil perhitungan model pada senyawa AOX di Sungai Ciujung baik dihulu maupun hilir. Hasil kalibrasi ini menunjukkan bahwa model dapat digunakan untuk melakukan pengembangan berbagai variasi skenario simulasi.

\subsection{Simulasi Daya Tampung Beban Cemaran AOX Sungai Ciujung pada Debit Andalan Minimum dan Maksimum}

Konsentrasi senyawa AOX yang diperoleh dari hasil analisis sampel air Sungai Ciujung selanjutnya disimulasikan dengan program WASP7.3 pada debit andalan. Hasilnya dibandingkan dengan baku mutu senyawa AOX Negara Jerman yang mensyaratkan untuk sungai kelas 1 adalah $0 \mathrm{mg} / \mathrm{L}$, sungai kelas II maksimum $0.025 \mathrm{mg} / \mathrm{L}$, sungai kelas III maksimum $0.100 \mathrm{mg} / \mathrm{L}$ dan untuk sungai kelas IV maksimum $0.200 \mathrm{mg} / \mathrm{L}$.

Salah satu alternatif untuk meningkatkan kualitas Sungai Ciujung berdasarkan parameter senyawa AOX, yaitu dengan melakukan simulasi dengan cara merubah debit sungai, sedangkan debit limbah dan konsentrasi senyawa AOX dari point source yang masuk ke Sungai Ciujung tetap. Debit yang diinputkan adalah debit andalan Sungai Ciujung harian pada probabilitas $80 \%$. 
Jurnal SEOI - Fakultas Teknik Universitas Sahid Jakarta

Vol 1 edisi 1 tahun 2019

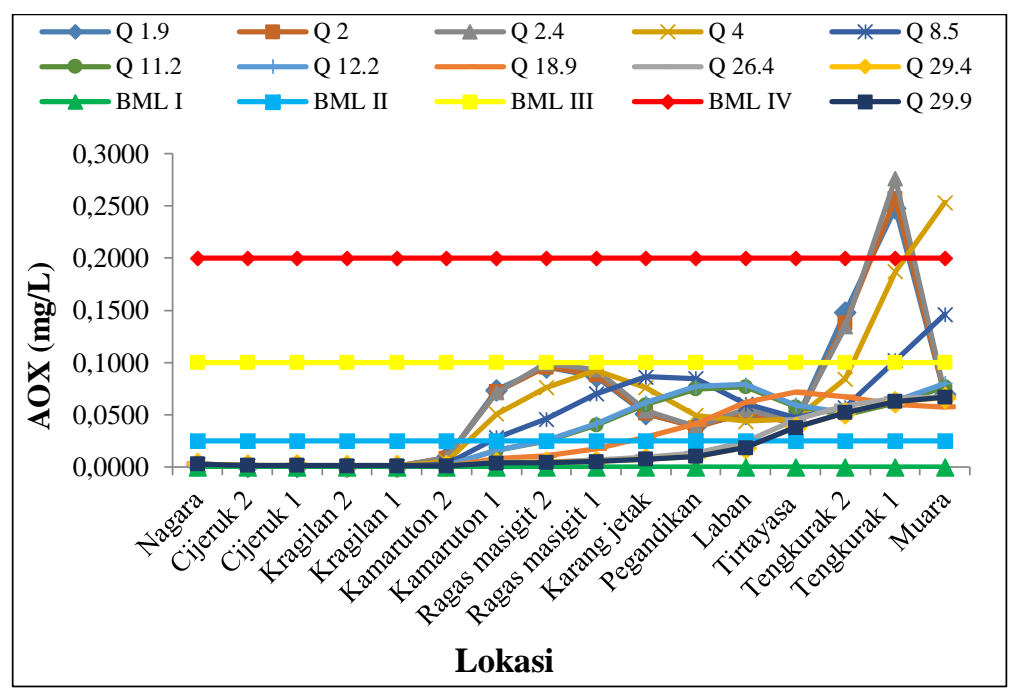

Gambar 5 Konsentrasi senyawa AOX hasil simulasi pada berbagai debit andalan

Hasil simulasi pada debit minimum, nampak bahwa konsentrasi senyawa AOX meningkat tajam di Kamaruton 1 pada km 16.25 sampai ke Muara (Gambar 6). Berdasarkan hasil simulasi tersebut, selanjutnya BP dihitung untuk menetapkan DTBP dan hasilnya disajikan dalam Gambar 5.

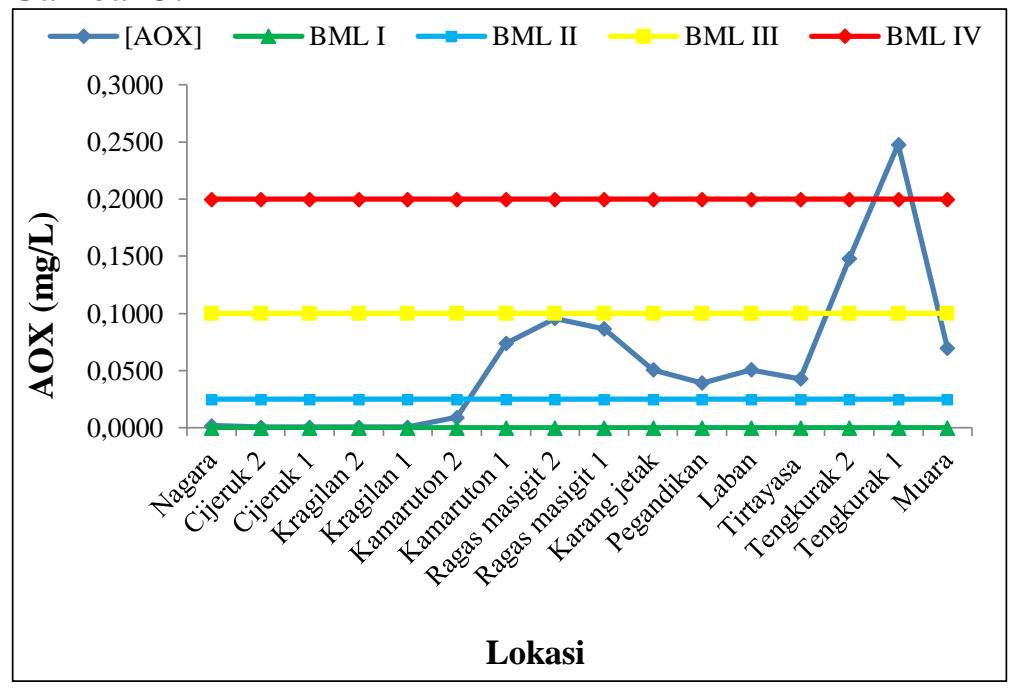

Gambar 6. Konsentrasi senyawa AOX pada debit minimum

Beban Pencemaran (BP) senyawa AOX di Sungai Ciujung pada debit minimumnya berkisar antara $0.1 \mathrm{~kg} / \mathrm{hari}-40,7 \mathrm{~kg} /$ hari, sedangkan BP yang diijinkan adalah $0 \mathrm{~kg} / \mathrm{hari}$ untuk sungai kelas I, $4.1 \mathrm{~kg} / \mathrm{hari}$ untuk sungai kelas II, $16.4 \mathrm{~kg} / \mathrm{hari}$ untuk sungai kelas III dan 32.8 $\mathrm{kg} / \mathrm{hari}$ untuk sungai kelas IV . Sehingga berdasarkan Tabel 2, dapat dilihat bahwa BP senyawa AOX di Sungai Ciujung tidak ada yang memenuhi untuk sungai kelas I, sedangkan yang memenuhi sungai kelas II, III dan IV berturut-turut adalah sepanjang $13.75 \mathrm{~km}, 27.25 \mathrm{~km}$ dan $30 \mathrm{~km}$. Hasil yang lebih jelas untuk BP dan DTBP jika dibandingkan dengan BP yang diijinkan pada debit $1.9 \mathrm{~m}^{3} /$ detik disajikan pada Gambar 6 .

Gambar 6 menunjukkan bahwa BP senyawa AOX tidak ada yang memenuhi untuk sungai kelas I. Sementara yang memenuhi sungai kelas II adalah sepanjang $13.75 \mathrm{~km}$ (NagaraKamaruton 2) dengan DTBP rata-rata yang masih bisa diterima lokasi tersebut adalah 3.73 $\mathrm{kg} / \mathrm{hari}$, yang memenuhi air sungai kelas III sepanjang $28.25 \mathrm{~km}$ (Tirtayasa dan Muara) dengan DTBP rata-rata pada lokasi tersebut $10.29 \mathrm{~kg} / \mathrm{hari}$ dan yang memenuhi kelas IV sepanjang 30 km (seluruh lokasi kecuali Tengkurak I) dengan DTBP rata-rata pada lokasi tersebut 25.49 $\mathrm{kg} / \mathrm{hari}$. Lokasi yang tidak memiliki DTBP adalah Tengkurak 1 sepanjang $1.75 \mathrm{~km}$. 
Jurnal SEOI - Fakultas Teknik Universitas Sahid Jakarta

Vol 1 edisi 1 tahun 2019

Tabel 2. DTBP AOX pada debit minimum

\begin{tabular}{|c|c|c|c|c|c|c|}
\hline \multirow{2}{*}{$\begin{array}{c}\text { Jarak } \\
(\mathbf{k m})\end{array}$} & \multirow{2}{*}{ Lokasi } & \multirow{2}{*}{$\begin{array}{c}\text { Beban } \\
\text { Pencemaran } \\
\text { (kg/hari) }\end{array}$} & \multicolumn{4}{|c|}{$\begin{array}{c}\text { Daya Tampung Beban Pencemaran } \\
\text { (kg/hari) }\end{array}$} \\
\hline & & & Kelas I & Kelas II & Kelas III & Kelas IV \\
\hline 1.75 & Nagara & 0.30 & -0.30 & 3.81 & 16.12 & 32.53 \\
\hline 4.25 & Cijeruk 2 & 0.11 & -0.11 & 3.99 & 16.30 & 32.72 \\
\hline 6 & Cijeruk 1 & 0.11 & -0.11 & 3.99 & 16.30 & 32.72 \\
\hline 9.25 & Kragilan 2 & 0.11 & -0.11 & 3.99 & 16.30 & 32.72 \\
\hline 11.25 & Kragilan 1 & 0.11 & -0.11 & 3.99 & 16.30 & 32.72 \\
\hline 13.75 & Kamaruton 2 & 1.48 & -1.48 & 2.63 & 14.94 & 31.36 \\
\hline 16.25 & Kamaruton 1 & 12.10 & -12.10 & -8.00 & 4.31 & 20.73 \\
\hline 18.25 & Ragas masigit 2 & 15.72 & -15.72 & -11.62 & 0.69 & 17.11 \\
\hline 20 & Ragas masigit 1 & 14.22 & -14.22 & -10.11 & 2.20 & 18.61 \\
\hline 21.75 & Karang jetak & 8.33 & -8.33 & -4.23 & 8.08 & 24.50 \\
\hline 23.25 & Pegandikan & 6.43 & -6.43 & -2.33 & 9.98 & 26.40 \\
\hline 25 & Laban & 8.32 & -8.32 & -4.22 & 8.09 & 24.51 \\
\hline 27.25 & Tirtayasa & 7.00 & -7.00 & -2.90 & 9.41 & 25.83 \\
\hline 29 & Tengkurak 2 & 24.34 & -24.34 & -20.23 & -7.92 & 8.49 \\
\hline 30.75 & Tengkurak 1 & 40.69 & -40.69 & -36.58 & -24.27 & -7.86 \\
\hline 31.75 & Muara & 11.42 & -11.42 & -7.31 & 5.00 & 21.41 \\
\hline \multicolumn{2}{|c|}{$\begin{array}{c}\text { Beban Pencemaran yang } \\
\text { diijinkan untuk } \\
\text { (kg/hari) }\end{array}$} & $\begin{array}{l}\text { Kelas I } \\
\text { Kelas II } \\
\text { Kelas III } \\
\text { Kelas IV }\end{array}$ & & & $\begin{array}{l}0 \\
10 \\
42 \\
83\end{array}$ & \\
\hline
\end{tabular}

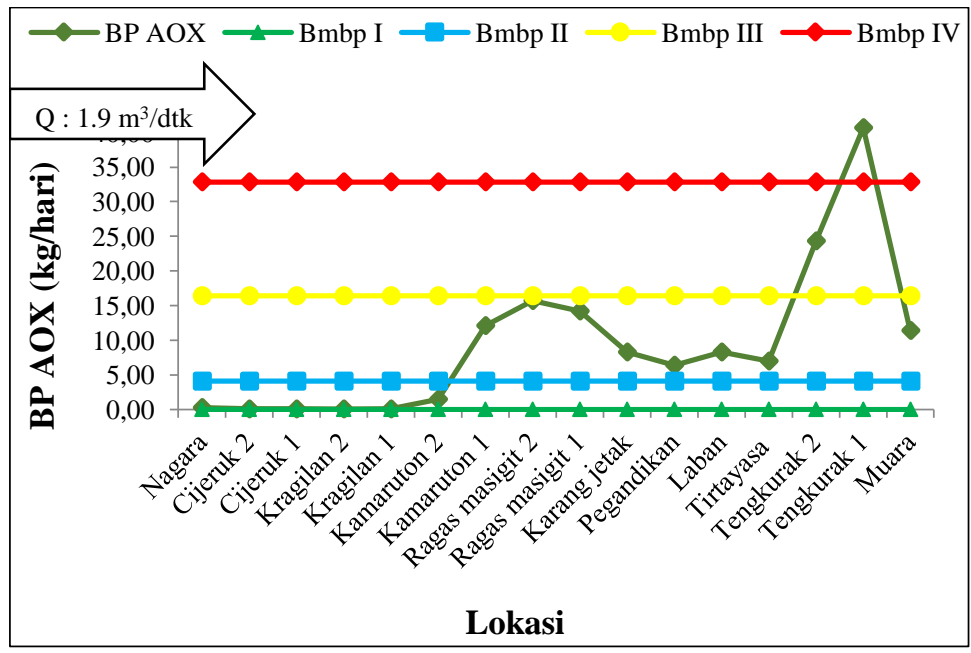

Gambar 7. Beban Pencemaran senyawa AOX pada Debit minimum

Jika dilihat berdasarkan DTBP rata-rata secara keseluruhan pada debit minimum, Sungai Ciujung tidak memiliki DTBP untuk senyawa AOX sebagai sungai kelas I $(-9.4 \mathrm{~kg} / \mathrm{hari})$ dan sungai kelas II (-5.3 kg/hari). Namun masih memiliki DTBP untuk sungai kelas III (7 kg/hari) dan sungai kelas IV $(23.4 \mathrm{~kg} / \mathrm{hari})$.

Konsentrasi senyawa AOX sepanjang sungai yang diperoleh dari hasil simulasi pada debit maksimum disajikan pada Gambar 7. 
Jurnal SEOI - Fakultas Teknik Universitas Sahid Jakarta

Vol 1 edisi 1 tahun 2019

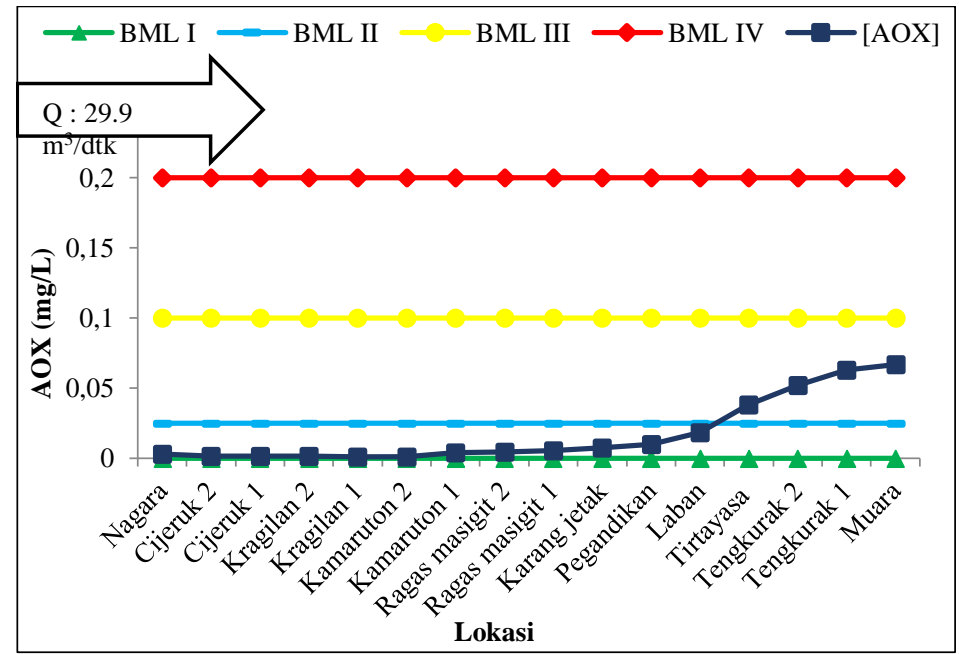

Gambar 8. Konsentrasi senyawa AOX pada debit maksimum

Hasil simulasi pada debit maksimum $\left(29.9 \mathrm{~m}^{3} /\right.$ detik) menunjukkan bahwa senyawa AOX tidak memenuhi kriteria mutu air kelas I di semua lokasi. Namun dapat memenuhi sungai kelas II sepanjang $25 \mathrm{~km}$ (Nagara-Laban) dan memenuhi sungai kelas III pada semua lokasi. Konsentrasi senyawa AOX hasil simulasi ini selanjutnya digunakan untuk menetapkan BP guna mengetahui DTBP AOX, dan hasilnya tercantum dalam Tabel 3.

BP AOX Sungai Ciujung pada debit maksimumnya berkisar antara $3 \mathrm{~kg} / \mathrm{hari}-173$ $\mathrm{kg} / \mathrm{hari}$ dengan BP rata-rata $55 \mathrm{~kg} / \mathrm{hari}$, sedangkan BP yang diijinkan untuk sungai kelas I sampai IV berturut-turut adalah $0 \mathrm{~kg} / \mathrm{hari}, 65 \mathrm{~kg} / \mathrm{hari}, 258 \mathrm{~kg} / \mathrm{hari}$ dan $517 \mathrm{~kg} / \mathrm{hari}$. Pada saat debit maksimum, Sungai Ciujung tidak memenuhi sungai kelas I sehingga tidak memiliki DTBP (-45 kg/hari). Namun Sungai Ciujung dapat memenuhi sungai kelas II sepanjang $25 \mathrm{~km}$ (Nagara-Laban) dengan DTBP rata-rata yang masih bisa diterima lokasi tersebut adalah 52 $\mathrm{kg} / \mathrm{hari}$, dan seluruh lokasi dapat memenuhi sungai kelas III dengan DTBP rata-rata $213 \mathrm{~kg} / \mathrm{hari}$. Hasil yang lebih jelas untuk perbedaan BP dan DTBP sepanjang sungai jika dibandingkan dengan BP yang diijinkan disajikan pada Gambar 9.

Peningkatan debit berdampak pada peningkatan kualitas air Sungai Ciujung sehingga meningkatkan DTBP. Pada saat debit minimum $\left(1.9 \mathrm{~m}^{3} / \mathrm{detik}\right)$ dinaikan menjadi debit maksimum (29.9 $\mathrm{m}^{3} /$ detik), lokasi sungai yang memenuhi sungai kelas II meningkat sebesar $81.82 \%$, dari $13.75 \mathrm{~km}$ menjadi $25 \mathrm{~km}$ dengan peningkatan DTBP rata-rata sebesar $3.73 \mathrm{~kg} / \mathrm{hari}$ menjadi $52 \mathrm{~kg} / \mathrm{hari}$. Peningkatan lokasi yang memenuhi sungai kelas III sebesar $12.39 \%$ dari $28.25 \mathrm{~km}$ menjadi $31.75 \mathrm{~km}$ dengan peningkatan DTBP rata-rata $10 \mathrm{~kg} / \mathrm{hari}$ menjadi 213 $\mathrm{kg} / \mathrm{hari}$. Sementara peningkatan DTBP rata-rata untuk memenuhi baku mutu sungai kelas IV adalah $446 \mathrm{~kg} / \mathrm{hari}$ dari $26 \mathrm{~kg} / \mathrm{hari}$ menjadi $472 \mathrm{~kg} / \mathrm{hari}$.

Tabel 3. DTBP AOX pada debit maksimum

\begin{tabular}{rlccccc}
\hline \multirow{2}{*}{$\begin{array}{c}\text { Jarak } \\
(\mathbf{k m})\end{array}$} & \multirow{2}{*}{$\begin{array}{c}\text { Segmen } \\
\text { Pencemaran }\end{array}$} & \multicolumn{4}{c}{$\begin{array}{c}\text { Daya Tampung Beban Pencemaran } \\
\text { (kg/hari) }\end{array}$} \\
\cline { 4 - 7 } & & Nag/hari) & Kelas I & Kelas II & Kelas III & Kelas IV \\
\hline 1.75 & Nagara & 7.49 & -7.49 & 57.09 & 250.84 & 509.18 \\
4.25 & Cijeruk 2 & 4.28 & -4.28 & 60.31 & 254.06 & 512.39 \\
6 & Cijeruk 1 & 4.05 & -4.05 & 60.54 & 254.29 & 512.63 \\
9.25 & Kragilan 2 & 3.60 & -3.60 & 60.99 & 254.74 & 513.08 \\
11.25 & Kragilan 1 & 3.35 & -3.35 & 61.23 & 254.98 & 513.32 \\
13.75 & Kamaruton 2 & 2.94 & -2.94 & 61.65 & 255.40 & 513.73 \\
16.25 & Kamaruton 1 & 10.39 & -10.39 & 54.20 & 247.95 & 506.29 \\
18.25 & Ragas masigit 2 & 11.33 & -11.33 & 53.26 & 247.01 & 505.34
\end{tabular}


Jurnal SEOI - Fakultas Teknik Universitas Sahid Jakarta

Vol 1 edisi 1 tahun 2019

\begin{tabular}{rlrrrrr}
20 & Ragas masigit 1 & 13.89 & -13.89 & 50.70 & 244.45 & 502.78 \\
21.75 & Karang jetak & 19.24 & -19.24 & 45.34 & 239.09 & 497.43 \\
23.25 & Pegandikan & 26.30 & -26.30 & 38.29 & 232.04 & 490.38 \\
25 & Laban & 47.71 & -47.71 & 16.87 & 210.62 & 468.96 \\
27.25 & Tirtayasa & 98.12 & -98.12 & -33.53 & 160.22 & 418.55 \\
29 & Tengkurak 2 & 134.89 & -134.89 & -70.30 & 123.45 & 381.78 \\
30.75 & Tengkurak 1 & 162.26 & -162.26 & -97.67 & 96.08 & 354.41 \\
31.75 & Muara & 172.66 & -172.66 & -108.08 & 85.68 & 344.01 \\
\hline \multirow{2}{*}{$\begin{array}{c}\text { Beban Pencemaran yang } \\
\text { diijinkan untuk } \\
\text { (kg/hari) }\end{array}$} & Kelas I & & & 0.00 & \\
& Kelas II & & & 258 & \\
\end{tabular}

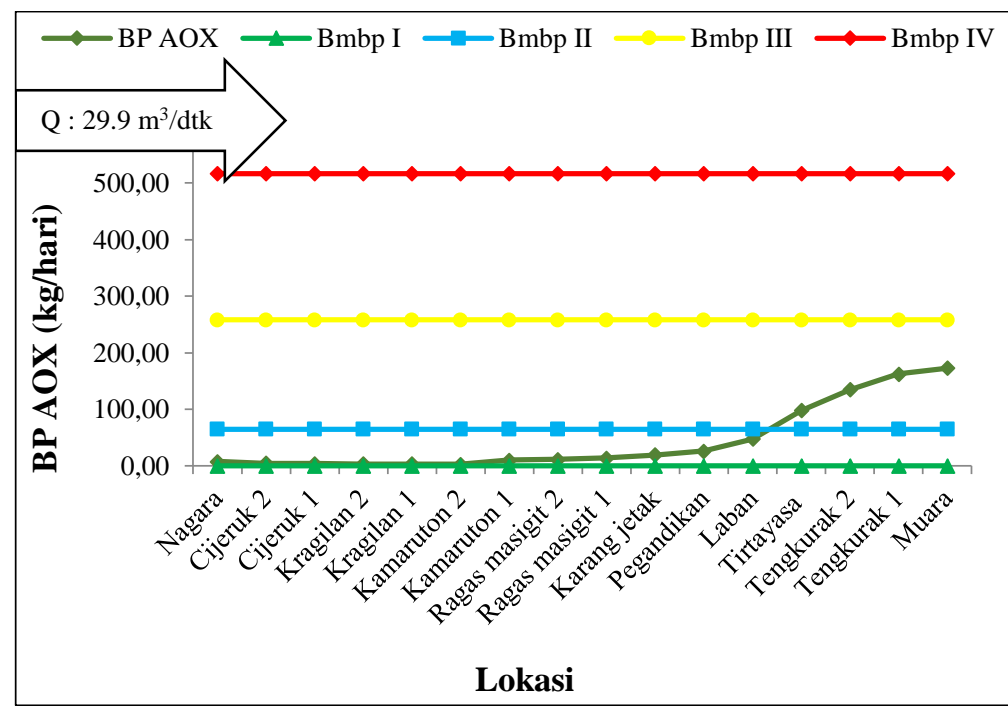

Gambar 9. Beban Pencemaran senyawa AOX pada Debit maksimum

\subsection{Simulasi DTBP Senyawa AOX dengan Merubah Debit dan Mereduksi Beban Pencemaran}

Hasil simulasi senyawa AOX yang telah dilakukan pada debit maksimum, menunjukkan adanya peningkatan kualitas dan DTBP. Namun di beberapa lokasi masih ada yang belum memenuhi kriteria mutu air sungai kelas II, sehingga simulasi selanjutnya dilakukan dengan mereduksi potensi BP dari PS pada debit minimum dan maksimumnya. Konsentrasi senyawa AOX yang diperoleh dari hasil simulasi dengan menurunkan potensi beban pencemaran PS sebesar 25\%, 50\%, 75\% dan 90\% disajikan pada Gambar 10.
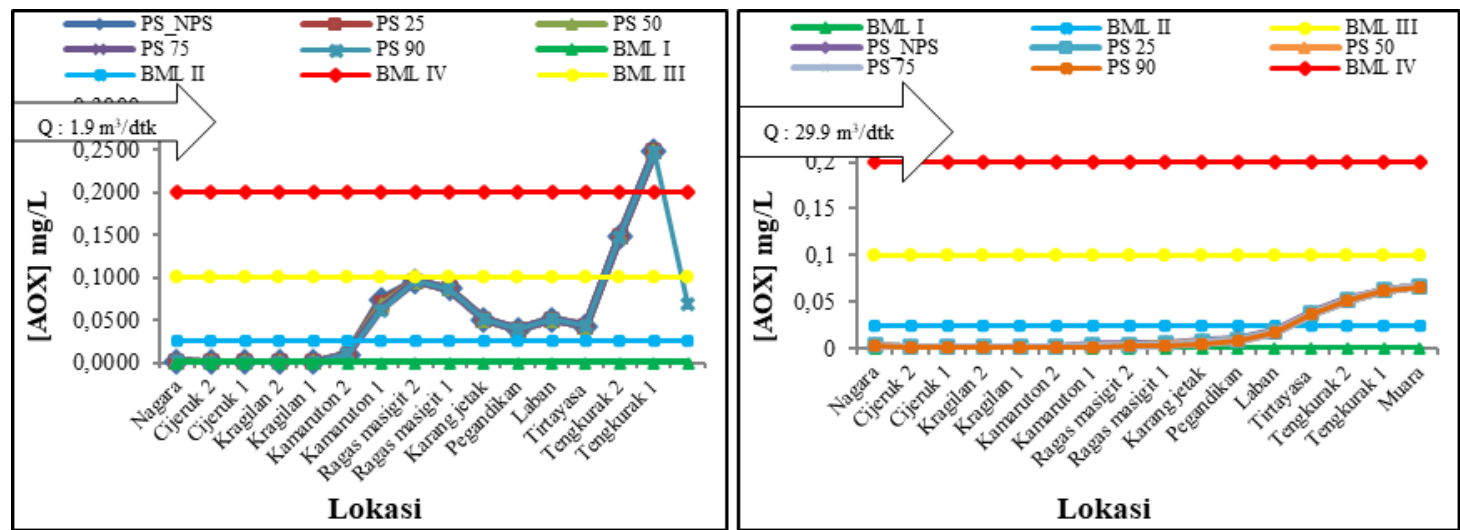
Gambar 10. Konsentrasi senyawa AOX hasil simulasi dengan mereduksi BP dari PS pada saat (a) debit minimum dan (b) debit maksimum

Hasil simulasi dengan mereduksi BP yang dilakukan pada debit maksimum dan minimum menunjukkan kondisi kualitas air sungai yang sama. Hasil simulasi pada debit minimum memperlihatkan bahwa penurunan konsentrasi AOX terjadi hanya di Kamaruton 1, yang mana sebelum dilakukan reduksi konsentrasi AOX $0.0737 \mathrm{mg} / \mathrm{L}$ dan ketika BP dari PS direduksi 90\% maka konsentrasi AOX menurun $16.28 \%$ menjadi $0.0617 \mathrm{mg} / \mathrm{L}$. Sedangkan dilokasi lainnya reduksi BP tidak memberikan perubahan pada kualitas air sungai. Simulasi yang dilakukan pada debit maksimum (Gambar 10b) memperlihatkan bahwa peningkatan reduksi BP menyebabkan konsentrasi senyawa AOX menurun mulai dari Kamaruton 1 sampai ke Muara. BP sepanjang sungai Ciujung ditetapkan dari konsentrasi senyawa AOX hasil model guna mengetahui DTBP sungai setelah potensi BP dari PS direduksi baik pada debit minimum maupun maksimum, hasilnya tercantum pada Tabel 4. dan Gambar 11.

Tabel 4. DTBP AOX setelah BP dari PS direduksi $90 \%$ pada saat debit minimum

\begin{tabular}{|c|c|c|c|c|c|c|}
\hline \multirow{2}{*}{$\begin{array}{c}\text { Jarak } \\
(\mathbf{k m})\end{array}$} & \multirow[t]{2}{*}{ Segmen } & \multirow{2}{*}{$\begin{array}{c}\text { Beban } \\
\text { Pencemaran } \\
\text { (kg/hari) } \\
\end{array}$} & \multicolumn{4}{|c|}{$\begin{array}{c}\text { Daya Tampung Beban Pencemaran } \\
\text { (kg/hari) }\end{array}$} \\
\hline & & & Kelas I & Kelas II & Kelas III & Kelas IV \\
\hline 1.75 & Nagara & 0.30 & -0.30 & 3.81 & 16.12 & 32.53 \\
\hline 4.25 & Cijeruk 2 & 0.11 & -0.11 & 3.99 & 16.30 & 32.72 \\
\hline 6 & Cijeruk 1 & 0.11 & -0.11 & 3.99 & 16.30 & 32.72 \\
\hline 9.25 & Kragilan 2 & 0.11 & -0.11 & 3.99 & 16.30 & 32.72 \\
\hline 11.25 & Kragilan 1 & 0.11 & -0.11 & 3.99 & 16.30 & 32.72 \\
\hline 13.75 & Kamaruton 2 & 1.48 & -1.48 & 2.63 & 14.94 & 31.36 \\
\hline 16.25 & Kamaruton 1 & 10.13 & -10.13 & -6.03 & 6.29 & 22.70 \\
\hline 18.25 & Ragas masigit 2 & 15.72 & -15.72 & -11.62 & 0.69 & 17.11 \\
\hline 20 & Ragas masigit 1 & 14.22 & -14.22 & -10.11 & 2.20 & 18.61 \\
\hline 21.75 & Karang jetak & 8.33 & -8.33 & -4.23 & 8.08 & 24.50 \\
\hline 23.25 & Pegandikan & 6.43 & -6.43 & -2.33 & 9.98 & 26.40 \\
\hline 25 & Laban & 8.32 & -8.32 & -4.22 & 8.09 & 24.51 \\
\hline 27.25 & Tirtayasa & 7.00 & -7.00 & -2.90 & 9.41 & 25.83 \\
\hline 29 & Tengkurak 2 & 24.34 & -24.34 & -20.23 & -7.92 & 8.49 \\
\hline 30.75 & Tengkurak 1 & 40.69 & -40.69 & -36.58 & -24.27 & -7.86 \\
\hline 31.75 & Muara & 11.42 & -11.42 & -7.31 & 5.00 & 21.41 \\
\hline \multicolumn{2}{|c|}{$\begin{array}{c}\text { Beban Pencemaran yang } \\
\text { diijinkan untuk } \\
\text { (kg/hari) }\end{array}$} & $\begin{array}{l}\text { Kelas I } \\
\text { Kelas II } \\
\text { Kelas III } \\
\text { Kelas IV }\end{array}$ & & & & \\
\hline
\end{tabular}

BP AOX sepanjang sungai hasil simulasi dengan mereduksi PS (limbah industri) $90 \%$ pada debit minimumnya berkisar antara $0.11 \mathrm{~kg} / \mathrm{hari}$ - $40.69 \mathrm{~kg} / \mathrm{hari}$ dengan BP rata-rata 9.30 $\mathrm{kg} / \mathrm{hari}$, sedangkan BP yang diijinkan untuk sungai kelas I, II, III dan IV berturut-turut adalah $0 \mathrm{~kg} / \mathrm{hari} ; 4.10 \mathrm{~kg} / \mathrm{hari} ; 16.42 \mathrm{~kg} / \mathrm{hari}$ dan $32.83 \mathrm{~kg} / \mathrm{hari}$. Jika dibandingkan dengan kelas II, maka lokasi yang memenuhi adalah Nagara sampai Kamaruton 2 sepanjang 13.75 km, yang memenuhi kelas III adalah seluruh lokasi kecuali Tengkurak 2 dan Tengkurak 1 sepanjang $28.25 \mathrm{~km}$ sedangkan yang memenuhi kelas IV adalah Nagara sampai Muara kecuali Tengkurak 1 sepanjang $30.75 \mathrm{~km}$. Hasil yang lebih jelas untuk perbedaan BP jika dibandingkan dengan hasil simulasi semua kelas pada debit minimum disajikan pada Gambar 11. 
Jurnal SEOI - Fakultas Teknik Universitas Sahid Jakarta

Vol 1 edisi 1 tahun 2019

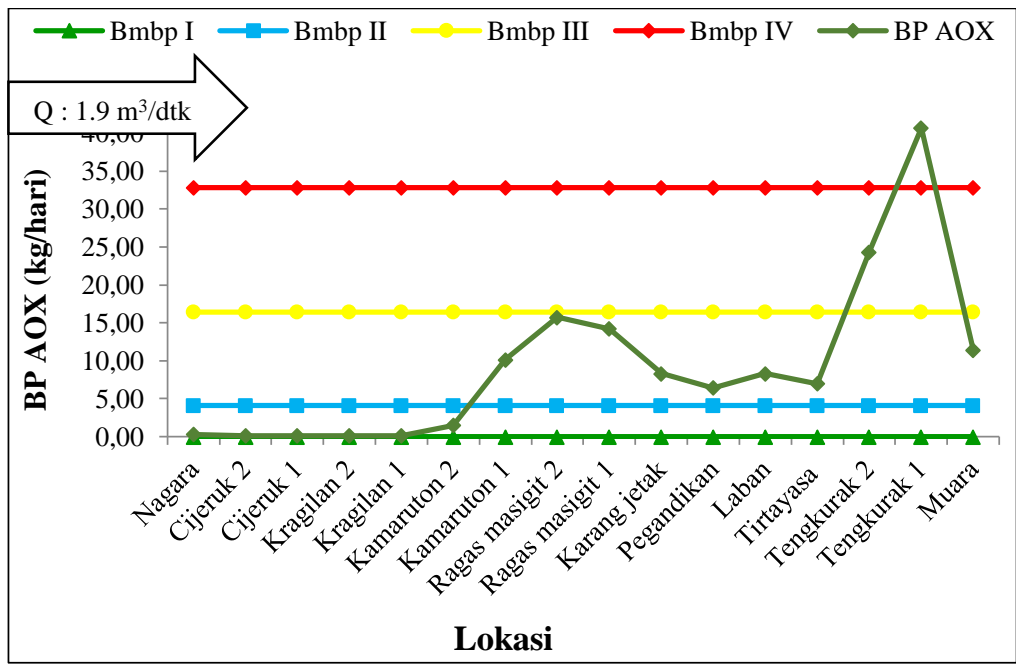

Gambar 11. BP AOX setelah PS direduksi $90 \%$ pada saat debit minimum

Gambar di atas menunjukkan bahwa ketika BP dari PS direduksi 90\%, maka BP di sepanjang sungai Ciujung sudah tidak memiliki DTBP untuk memenuhi sungai kelas I. Sementara DTBP rata-rata yang dimiliki untuk memenuhi kelas II adalah $3.73 \mathrm{~kg} / \mathrm{hari}$, DTBP rata-rata yang masih dimiliki untuk semua lokasi kecuali Tengkurak 1 dan 2 sepanjang 28.25 $\mathrm{km}$ adalah $39.31 \mathrm{~kg} / \mathrm{hari}$ untuk memenuhi kelas III, dan DTBP rata-rata yang masih dimiliki untuk memenuhi kelas IV di semua lokasi kecuali Tengkurak 1 sepanjang $30 \mathrm{~km}$ adalah 31.39 $\mathrm{kg} /$ hari. Sehingga lokasi yang tidak memiliki DTBP adalah Lokasi Tengkurak 1 sepanjang 1.75 $\mathrm{km}$.

Hasil simulasi senyawa AOX pada debit maksimum menunjukkan bahwa selalu ada peningkatan kualitas air sungai ketika BP dari PS direduksi seperti yang ditunjukkan pada Gambar 5.20. Perbedaan yang nyata nampak di Kamaruton 1, yang mana pada lokasi tersebut terjadi penurunan konsentrasi AOX yang cukup tajam sebesar $97.7 \%$ dari $0.0737 \mathrm{mg} / \mathrm{L}$ menjadi $0.0017 \mathrm{mg} / \mathrm{L}$ setelah beban limbah industri direduksi sebesar 90\%, sehingga pada lokasi ini parameter AOX memenuhi kriteria mutu air sungai kelas II.

BP dan DTBP dari hasil simulasi yang dilakukan dengan mereduksi limbah industri sebesar $90 \%$ pada debit maksimum, dapat dilihat pada Tabel 5 dan Gambar 11. di bawah ini.

Tabel 5 DTBP AOX setelah BP dari PS direduksi 90\% pada saat debit maksimum

\begin{tabular}{rlccccc}
\hline \multirow{2}{*}{$\begin{array}{c}\text { Jarak } \\
(\mathbf{k m})\end{array}$} & Segmen & $\begin{array}{c}\text { Beban } \\
\text { Pencemaran } \\
(\mathbf{k g} / \text { hari) }\end{array}$ & \multicolumn{4}{c}{$\begin{array}{c}\text { Daya Tampung Beban Pencemaran } \\
\text { (kg/hari) }\end{array}$} \\
\cline { 4 - 7 } & & 7.49 & -7.49 & 57.09 & 250.84 & 509.18 \\
1.75 & Nagara & 4.28 & -4.28 & 60.31 & 254.06 & 512.39 \\
4.25 & Cijeruk 2 & 4.05 & -4.05 & 60.54 & 254.29 & 512.63 \\
6 & Cijeruk 1 & 3.60 & -3.60 & 60.99 & 254.74 & 513.08 \\
9.25 & Kragilan 2 & 3.35 & -3.35 & 61.23 & 254.98 & 513.32 \\
11.25 & Kragilan 1 & 2.94 & -2.94 & 61.65 & 255.40 & 513.73 \\
13.75 & Kamaruton 2 & 4.30 & -4.30 & 60.28 & 254.04 & 512.37 \\
16.25 & Kamaruton 1 & 5.47 & -5.47 & 59.11 & 252.86 & 511.20 \\
18.25 & Ragas masigit 2 & 8.27 & -8.27 & 56.31 & 250.06 & 508.40 \\
20 & Ragas masigit 1 & 13.89 & -13.89 & 50.69 & 244.44 & 502.78 \\
21.75 & Karang jetak & 21.19 & -21.19 & 43.39 & 237.14 & 495.48 \\
23.25 & Pegandikan & 43.16 & -43.16 & 21.43 & 215.18 & 473.51 \\
25 & Laban & 94.80 & -94.80 & -30.21 & 163.54 & 421.87 \\
27.25 & Tirtayasa & 132.55 & -132.55 & -67.97 & 125.78 & 384.12 \\
29 & Tengkurak 2 & 160.87 & -160.87 & -96.29 & 97.47 & 355.80 \\
30.75 & Tengkurak 1 & & &
\end{tabular}


Jurnal SEOI - Fakultas Teknik Universitas Sahid Jakarta

Vol 1 edisi 1 tahun 2019

\begin{tabular}{|c|c|c|c|c|}
\hline Muara & 171.77 & -171.77 & -107.19 & 344.90 \\
\hline \multirow{4}{*}{$\begin{array}{l}\text { Beban Pencemaran yang } \\
\text { diijinkan untuk } \\
\text { (kg/hari) }\end{array}$} & Kelas I & & 0.00 & \\
\hline & Kelas II & & 64.58 & \\
\hline & Kelas III & & 258.34 & \\
\hline & Kelas IV & & 516.67 & \\
\hline
\end{tabular}

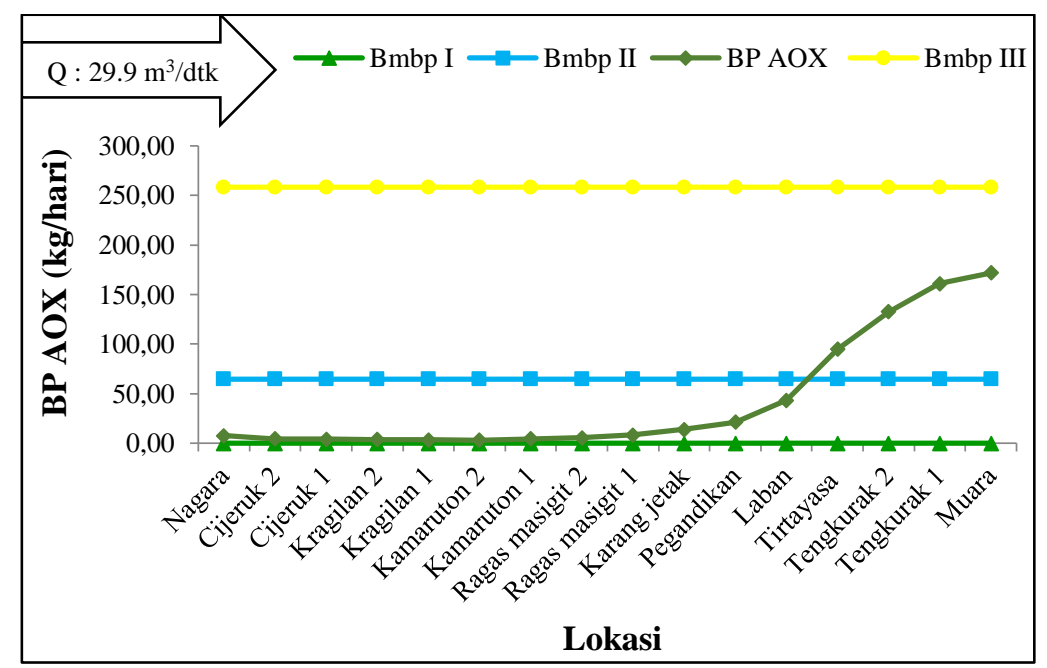

Gambar 12 Beban Pencemaran AOX setelah PS direduksi 90\% pada saat debit maksimum

Tabel 5 dan Gambar 12 menunjukkan bahwa BP di lokasi Nagara sampai Laban sepanjang $25 \mathrm{~km}$ telah memenuhi kriteria mutu air sungai kelas II dengan DTBP rata-rata yang dimiliki $57.42 \mathrm{~kg} /$ hari, sedangkan jika dibandingkan dengan kriteria mutu air sungai kelas III maka seluruh lokasi telah memenuhi dengan DTBP rata-rata yang dimiliki $215.71 \mathrm{~kg} / \mathrm{hari}$.

Peningkatan kualitas air sungai terjadi ketika debit dinaikan dari $1.9 \mathrm{~m}^{3} /$ detik menjadi $29.9 \mathrm{~m}^{3} /$ detik dengan mereduksi limbah industri sebesar $90 \%$. Lokasi yang memenuhi kelas II meningkat $81.82 \%$ dari $13.75 \mathrm{~km}$ menjadi $25 \mathrm{~km}$ dan yang memenuhi kelas III meningkat $5.83 \%$ dari $30 \mathrm{~km}$ menjadi $31.75 \mathrm{~km}$.

\section{Kesimpulan}

Peningkatan kualitas air sungai terjadi ketika debit dinaikan dari $1.9 \mathrm{~m}^{3} /$ detik menjadi $29.9 \mathrm{~m}^{3} /$ detik. Lokasi yang memenuhi kelas II meningkat sebesar $81,82 \%$ dari $13.75 \mathrm{~km}$ menjadi $25 \mathrm{~km}$ dengan peningkatan daya tampung beban pencemaran rata-rata sebesar 3,73 $\mathrm{kg} / \mathrm{hari} \mathrm{menjadi} 52 \mathrm{~kg} / \mathrm{hari}$.

Hasil simulasi dengan menggunakan debit andalan maksimum pada probabilitas $80 \%$ dan reduksi beban pencemaran dari point source sebesar $90 \%$ menunjukkan bahwa kualitas air sungai Ciujung pada Segmen Nagara sampai Laban $(25 \mathrm{Km})$ dapat memenuhi baku mutu sungai kelas II dengan daya tampung beban pencemaran rata-rata 57,42 kg/hari. beban pencemaran untuk parameter AOX (DTBP -5.32 kg/hari).

\section{Daftar Pustaka}

Ambrose R B. (2005). The Water Quality Analysis Simulation Program WASP5 Part A : Model Documentation. US.EPA. 
Ambrose R B. (2009). WASP7 Stream Transport : Model Theory and User's Guide. US EPA. Georgia.

[DLH] Badan Lingkungan Hidup. (2017). Status Lingkungan Kabupaten Serang Tahun 2016. Serang (ID) : Badan Lingkungan Hidup Kabupaten Serang.

[KLH] Kementerian Lingkungan Hidup. (2004). Peraturan Pemerintah Republik Indonesia Nomor 82 Tahun 2001 tentang Pengelolaan Kualitas Air dan Pengendalian Pencemaran Air. Jakarta (ID) : Kementrian Lingkungan Hidup.

Nurmala. (2010). Status Mutu Air Dan Estimasi Daya Tampung Beban Pencemaran Organik Di Sungai Ciujung Provinsi Banten [tesis]. Jakarta (ID) : Sekolah Tinggi Manajemen IMNI.

[SNI] Standar Nasional Indonesia. (1991) No 06-2421-1991 tentang Metode Pengambilan Contoh Uji Kualitas Air. Jakarta (ID) : BSN.

[SNI]Standar Nasional Indonesia. (2011). Standar Nasional Indonesia No 7228.2:211 tentang Metode Pengujian Senyawa AOX. Jakarta (ID) : BSN.

Sutisna A. (2002). Laporan Status Lingkungan Hidup Indonesia Tahun 2002. Jakarta (ID) : Kementerian Negara Lingkungan Hidup Republik Indonesia.

US EPA[United States Environmental Protection Agency]. (2008). Final Total Maximum Daily Load (TMDL) for Organic Enrichment \& Dissolved oxygen. Georgia: US EPA Region 4.

Yasmidi. (2008). Analisis Kandungan Senyawa Organik Terklorinasi (AOX) pada Perairan di Sekitar Industri Pulp dan Kertas [tesis]. Bandung (ID) : ITB 